\title{
Evaluation of efficacy of Navakarshik Kwath Ghan in Sheetpitta with special reference to Urticaria
}

\author{
Research Article
}

\section{Rohan Rathod1*, Pooja P Thakre1, Vinod Ade ${ }^{2}$}

1. PG Scholar, 2. Professor, Department of Kayachikitsa, Mahatma Gandhi Ayurveda College, Hospital and Research Center, Salod (H) Wardha

\begin{abstract}
Background: Sheetapitta (Urticaria) is one among the Tvak Vikara (Skin disease) that have similar Hetu (Cause) of Kotha and Udarda. Vata and Kapha are two "Doshas" (energies), which are primarily, disturbed which in turn is associated with Pitta resulting in Tridosha Prakopa (Aggravation of three energies) leading to redness, swelling itching on the skin etc. Symptoms include appearance of wheals all over the body with severe itching, burning sensation and pain. Symptomatology and causative factors of Sheetapitta can be considered similar to that of 'Urticaria'. Aim: This clinical study was carried out to evaluation of efficacy in Sheetpitta with special reference to Urticaria. Material - Navakarshik Kwath Ghan in dose of 2 tab of $500 \mathrm{mg}$ twice a day with water after meal in duration of 15 days. Methodology - In this study include single group of 30 subjects of either gender in the age group of 16-60 years having complaining of reddish wheals, itching and pricking pain on body. Observation and Result Data regarding age wise, sex wise, allergy wise, diet wise, Prakruti (Nature) wise, hematological parameters and UAS (Urticarial Activity Score). Conclusion - Internal use of Navakarshik Kwath Ghan is found effective in the severity of itching.
\end{abstract}

Key Words: Sheetpitta, Koth,Udard, Tridosha Prakop, Urticaria, Navakarshik Kwath Ghan.

\section{Introduction}

In present life style, one can't follow the rules of 'Dinacharya'(Daily regimen) and 'Ritucharya' (Seasonal regimen) described in 'Ayurveda'. Due to industrialization and traffic one constantly comes into contact with various pollutants. The spicy and fast food eaten now a days, which have very less nutritional values and also having similar properties to 'Viruddhahara'(Incremental). These all ultimately resulted into 'Dhatudurbalya'(Tissue debilation), which causes sensitization towards allergens as well as antibodies and produces various types of allergic reactions, one of them is 'Urticaria', which is very common.

Urticaria is such a widespread debilitating condition having highest impact on quality of life and required most visits to the Emergency Department. It affects about $15-20 \%$ of total population(1) . It is a vascular reaction characterized by transient, erythematous swelling over the skin and/or on mucus membranes which may appear on any part of the body. They are usually transient and resolve in a few hours.(2) It makes the patient restless due to severe itching,

* Corresponding Author:

\section{Rohan Rathod}

PG scholar

Department of Kayachikitsa, Mahatma Gandhi

Ayurveda College, Hospital and Research Center,

Salod (H) Wardha, India

Email Id: Rohanrathod21@gmail.com burning sensation and pain. The symptoms of Urticaria are similar to Sheetpitta-Udarda-Kotha.

Skin allergies frequently cause rashes, or swelling and inflammation within the skin, which is known as a "wheal and flare" reaction characteristic of hives (Urticaria) and angioedema. Itching is a common characteristic of nonexfoliative skin disorders; these may be associated with burning sensation, change of colour etc. Out of these nonexfoliative skin diseases Sheetpitta (Urticaria) is one of the common dermatoses found all over the world. In Ayurveda, allergic manifestation is mentioned under the concept of Satmya-asatmya (Beneficial-non beneficial).(3) It manifests due to exposure to Asatmya Aharavihara(Non beneficial diet and regimen) and contact with different poisonous materials (allergens). Symptoms of allergic skin reaction is mentioned as Kotha in Brihata Trayi later on it is developed as separate disease under the title Sheetapitta-UdardaKotha by Acharya Madhavakara.(4) As the name Sheetpitta suggests the involvement of Vata and Pitta Doshas, along with Rasa and Rakta dhatus. Here the study is selected to find out simple, sure and effective medicament for Sheetpitta which have least or no side effect. For this purpose, Navkarshik Kwath Ghana from Bhaishjya ratnawali is selected for study.(5)

\section{Need of study}

As it is a very distressing, frustrating and challenging dermatological condition with no satisfactory treatment.(6) This study is taken to explore effective remedy for above condition. 
Aim and Objectives

Aim

"Evaluation of Efficacy of Navakarshika Kwatha Ghana in Sheetpitta with special reference to Urticaria”.

\section{Objectives}

- To explore the etiological factors of Sheetapitta

- To evaluate the efficacy of Navakarshika Kwatha Ghana in Sheetapitta

\section{Material and Methods}

\section{Source of material -}

The Patients were randomly selected from Kayachikitsa OPD of Mahatma Gandhi Ayurved College, Hospital \& Research center, Salod (H), Wardha with the features of Sheetpitta.

\section{Inclusion criteria}

- Patients of either sex in the age group of 16-60 years.

- Patients having classical clinical and recurrent features of Sheetapitta.

\section{Exclusion criteria}

- History of allergy to any medicine.

- Urticaria associated with other skin diseases.

- Acute Urticaria will be excluded.

\section{Investigations}

Before commencement of medication and after completing the medication $\mathrm{HB} \%$, ESR, Absolute Eosinophil count (AEC) was investigated.

\section{Methodology}

The patients were selected by simple random sampling method irrespective of their sex, religion and occupation. The informed consent was obtained from each patient before participation in the study. Total 34 patients were registered as per the inclusion criteria .Out of these, 30 patients have completed the treatment. Following treatment was given.

Navkarshika Kwatha Ghana which was prepared in Rasashala of Mahatma Gandhi Ayurved College, Hospital and Research Centre, Salod (H), Wardha. For the palatability of drug, the Navkarshika kwatha prepared in Ghana form , $500 \mathrm{mg} 2$ tablet twice a day was given orally with water after meals for continuous 15 days. If needed, tablet Cetirizine hydrochloride $5 \mathrm{mg}$ stat was given and it was recorded.

\section{Assessment Criteria}

The patients were treated for continuous 15 days and the assessment was done according to UAS (Urticaria activity score) and Itching score on 0th, 8th and 15 th day.

\section{Urticaria Activity Score (7)}

Table no. 1. Urticaria Activity Score

\begin{tabular}{|c|c|c|}
\hline Sr. no. & Wheals or hives & Grade \\
\hline 1 & None & 0 \\
\hline 2 & Mild $(<20$ wheals/24 h) & 1 \\
\hline 3 & Moderate $(21-50$ wheals/24 h) & 2 \\
\hline 4 & $\begin{array}{c}\text { Intense or severe }(>50 \text { wheals/ } \\
\text { 24 h or large confluent areas of } \\
\text { wheals })\end{array}$ & 3 \\
\hline & $\quad$\begin{tabular}{l} 
\\
\hline
\end{tabular} \\
\hline
\end{tabular}

\section{Severity of the Itching}

Table no. 2. Severity of the Itching

\begin{tabular}{|c|c|c|}
\hline Sr.no & Itching & Grade \\
\hline 1 & No Itching & 0 \\
\hline 2 & Mild / Occasional itching & 1 \\
\hline 3 & Moderate frequent itching & 2 \\
\hline 4 & Severe frequent itching & 3 \\
\hline 5 & Very severe itching, which disturb & 4 \\
\hline & sleep and other routine activity & \\
\hline
\end{tabular}

\section{Observation and Result}

The data obtained was coded and entered into Microsoft Excel Worksheet. The data was analyzed by using frequency distribution, descriptive statistics, analysis of variance and t-statistic with the help of statistical software SPSS 17.0 version and tabulated as below.

Table No. 3. Sex wise distribution of patients

\begin{tabular}{|c|c|c|}
\hline Sex & Frequency & Percentage (\%) \\
\hline Male & 16 & $53.3 \%$ \\
\hline Female & 14 & $46.7 \%$ \\
\hline Total & 30 & $100.0 \%$ \\
\hline
\end{tabular}

Total 30 patients were selected for study. It was found that out of these patients $16(53.3 \%)$ were male and $14(46.7 \%)$ were female.

Table No. 4. Age wise distribution of patients

\begin{tabular}{|c|c|c|}
\hline Age (Years) & Frequency & Percentage (\%) \\
\hline $16-26$ & 12 & $40.0 \%$ \\
\hline $27-37$ & 8 & $26.7 \%$ \\
\hline $38-48$ & 2 & $6.07 \%$ \\
\hline $49-60$ & 8 & $26.7 \%$ \\
\hline Total & 30 & $100.0 \%$ \\
\hline
\end{tabular}

Chi Square $=10.400 \mathrm{DF}=3 \mathrm{P}$ value $=0.006$ Significant.

In this series maximum no. of patients i.e. $40 \%$ belonged to age group of 16-26 years, $26.7 \%$ belonged to age group of 27-37 and 49-60, $6.7 \%$ belonged to age group of $38-48$ years.

Table No. 5. Allergy-wise (Food or Medicine) distribution of patients

\begin{tabular}{|c|c|c|}
\hline Allergy & Frequency & Percentage \% \\
\hline Yes & 12 & $40.0 \%$ \\
\hline No & 18 & $60.0 \%$ \\
\hline Total & 30 & $100.0 \%$ \\
\hline
\end{tabular}


In allergy- wise (food) distribution of patient, most of the patient were no allergy to any food in 18 $(60.0 \%)$ patients, $12(40.0 \%)$ of having allergy to food.

Table No. 6. Diet of patients

\begin{tabular}{|c|c|c|}
\hline Diet & Frequency & Percentage $\%$ \\
\hline Vegetarian & 19 & $63.03 \%$ \\
\hline Mixed & 11 & $36.7 \%$ \\
\hline Total & 30 & $100.0 \%$ \\
\hline
\end{tabular}

In table no.4, it was shows that $19(63.3 \%)$ patients were having vegetarian and $11(36.7 \%)$ patients were having mixed diet.
Table No.7. Prakruti of Patients

\begin{tabular}{|c|c|c|}
\hline Prakruti & Frequency & Percentage $\%$ \\
\hline Kaphaj pitta & 14 & $46.07 \%$ \\
\hline Kaphaj vataj & 2 & $6.7 \%$ \\
\hline Pittaj Kapha & 1 & $3.3 \%$ \\
\hline Pittaj vataj & 4 & $13.3 \%$ \\
\hline Vataj pitta & 9 & $30.0 \%$ \\
\hline Total & 30 & $100.0 \%$ \\
\hline
\end{tabular}

Chi Square $=19.667 \mathrm{DF}=4 \mathrm{P}$ value $=0.001$ Significant.

Analysis of data obtained reveals that majority of the patients $46.7 \%$ were having Kaphaj Pitta Prakruti and $30.0 \%$ patients were having Vata Pittaj, $13.3 \%$ patients were having Pittaj vata, 6.7\% patients were having Kaphaj vata and 3.3\% Pittaj Kapha Parakuti respectively.

Table No. 8. Mean Hb (in gm\%) of Patients

\begin{tabular}{|c|c|c|c|c|c|}
\hline Hb (in gm \%) & Mean & SD & $\begin{array}{c}\text { Std. Error } \\
\text { Mean }\end{array}$ & t-statistic & P value \\
\hline Before treatment & 12.56 & 1.50 & 0.27 & 2.248 & 0.032 \\
\hline After treatment & 12.92 & 1.66 & 0.30 & Significant \\
\hline
\end{tabular}

Mean of $\mathrm{Hb} \%$ before treatment were $12.56 \pm 1.50$ is and after treatment $12.92 \pm 1.66$ its $t$ value is 2.248 and its $p$ value is 0.032 which is statistically significant.

Table No.9. Mean ESR (/mm 1st hour) of Patients

\begin{tabular}{|c|c|c|c|c|c|}
\hline $\begin{array}{c}\text { Mean ESR (/ } \\
\text { mm 1st hour) }\end{array}$ & Mean & SD & $\begin{array}{c}\text { Std. Error } \\
\text { Mean }\end{array}$ & t-statistic & P value \\
\hline Before treatment & 27.97 & 19.83 & 3.62 & 5.248 & 0.001 \\
\hline After treatment & 19.69 & 16.27 & 2.97 & Significant \\
\hline
\end{tabular}

Mean of ESR before treatment were $27.97 \pm 19.18$ and after treatment $19.67 \pm 16.27$ and its $t$ value is 5.248 and its $p$ value is 0.001 it is statistically significant.

Table No. 10. Mean AEC (Absolute Eosinophil Count) (/cumm) of Patient

\begin{tabular}{|c|c|c|c|c|c|}
\hline $\begin{array}{c}\text { Mean AEC } \\
(/ \mathbf{c u m m})\end{array}$ & Mean & SD & $\begin{array}{c}\text { Std. Error } \\
\text { Mean }\end{array}$ & t-statistic & P value \\
\hline Before treatment & 157.70 & 57.36 & 10.47 & \multirow{2}{*}{0.311} & 0.758 \\
\hline After treatment & 161.40 & 76.65 & 13.99 & Non Significant \\
\hline
\end{tabular}

Mean of AEC (Absolute Eosinophil Count) before treatment was 157.70 \pm 57.36 it is in normal limit and after treatment $161 \pm 76.65$ and its $t$ value is 0.311 and its $P$ value is 0.758 statistically it is non-significant.

Table No. 11. Mean Tablet Cetirizine taken by the Patients

\begin{tabular}{|c|c|c|c|c|c|c|}
\hline & Mean & Effect of therapy & S.D. & Std. Error Mean & F- statistics & P value \\
\hline $\begin{array}{c}\text { Tab Cetirizine taken before } \\
\text { treatment }\end{array}$ & 4.63 & & 2.95 & 0.53 & & \\
\hline $\begin{array}{c}\text { Tab Cetirizine taken on 8th } \\
\text { day }\end{array}$ & 2.80 & $82.72 \%$ & 1.78 & 0.32 & 24.819 & $\begin{array}{c}0.001 \\
\text { Significant }\end{array}$ \\
\hline $\begin{array}{c}\text { Tab Cetirizine taken on } \\
\text { 15th day }\end{array}$ & 0.80 & & 1.81 & 0.21 & \\
\hline
\end{tabular}

The mean of Cetirizine taken by patients before treatment were $4.63 \pm 2.95$, at 8 th day it was $2.80 \pm 1.78$, at 15 th day $0.80 \pm 1.18$ and its $\mathrm{F}$ value is 24.819 and its $\mathrm{P}$ value is 0.001 , statistically significant difference was found in mean of tablet Cetirizine taken between 1st-15th day. 
Table No. 12. Mean UAS (Urticarial activity score) of Patients

\begin{tabular}{|c|c|c|c|c|c|c|}
\hline & Mean & $\begin{array}{c}\text { Effect of } \\
\text { therapy }\end{array}$ & S.D. & $\begin{array}{c}\text { Std. Error } \\
\text { Mean }\end{array}$ & F- statistics & P value \\
\hline UAS on 0th day & 2.20 & & 0.66 & 0.12 & & 0.001 \\
\hline UAS on 8th day & 1.53 & $83.63 \%$ & 0.57 & 0.10 & 63.789 & Significant \\
\hline UAS on 15th day & 0.36 & & 0.66 & 0.12 & &
\end{tabular}

In Urticarial activity score mean were at 0 th day $2.20 \pm 0.66$, at 8 th day $1.53 \pm 0.57$, at 15 th day $0.36 \pm 066$ it is statistically significant.

Table No. 13 Itching of Patients

\begin{tabular}{|c|c|c|c|c|c|c|}
\hline & Mean & $\begin{array}{l}\text { Effect of } \\
\text { therapy }\end{array}$ & S.D. & $\begin{array}{c}\text { Std. Error } \\
\text { Mean }\end{array}$ & F- statistics & P value \\
\hline Itching on 0th day & 3.53 & \multirow{3}{*}{$88.66 \%$} & 0.73 & 0.13 & \multirow{3}{*}{155.630} & \multirow{3}{*}{$\begin{array}{c}0.001 \\
\text { Significant }\end{array}$} \\
\hline Itching on 8th day & 2.20 & & 0.66 & 0.12 & & \\
\hline Itching on 15 th day & 0.40 & & 0.67 & 0.12 & & \\
\hline
\end{tabular}

Mean itching of patients at 0 th day were $3.53 \pm 073$, 8th day $2.20 \pm 0.66$, at 15 th day $0.40 \pm 0.67$ it is statistically significant..

Table no. 14. Overall effect of total therapy

\begin{tabular}{|c|c|c|}
$\begin{array}{c}\text { Percentage of overall } \\
\text { effect of therapy }\end{array}$ & No.of patient & Percentage \\
\hline $0-25 \%$ & 2 & $6.66 \%$ \\
\hline $25-50 \%$ & 1 & $3.33 \%$ \\
\hline $50-75 \%$ & 4 & $13.33 \%$ \\
\hline $75-100 \%$ & 23 & $76.66 \%$ \\
\hline
\end{tabular}

\section{Overall effect of total therapy}

- Mild improvement and Unchanged was observed in $6.66 \%$ of patients.

- Moderate improvement was observed $3.33 \%$ of patients.

- Marked improvement was noted in $13.33 \%$ of patients.

- Complete Remission was noted in $76.66 \%$ of patients.

\section{Discussion}

Urticaria is commonly manifested in 2 nd and 3rd decade of life.(8) In ourstudy also maximum no. of patients were found in 2nd and 3rd decade of life. This indicates more incidence of chronic Urticaria in youngsters, Ayurvedic texts have described Sheetpitta as Pittapradhana Tridoshaja Vyadhi. This is evident from above data as Sheetpitta is more prevalent in age group which was Pitta Pradhana. Primary outcome of the study was there is significant improvement in Urticarial Activity Score and secondary outcome was there is significant improvement in $\mathrm{Hb} \%$, ESR and AEC counts. Also decreased the rate of consumption of Tablet Cetirizine. The present study was conducted limited number of patients, limited period of assessment up to 15 days, long term follow up is necessary and proper pathological investigation could not done like IgE etc. Controversy raised that trial will done by taking comparative group with tab. Cetrizine. In future, due to unhealthy lifestyle like cold drinks, living in cold atmosphere may increase chances of urticaria. For that its need to more study by applying TLC, HPTLC for drugs.

\section{Probable Mode of Action-}

Navakarshik kwath Ghana contains Amalaki, Bibhitaki, Haritaki, Manjistha, Nimba, Vacha, Kutaki, Guduchi and Daruharidra possess with dominancy of Tikta (Bitter), Kashay (Asthingent )and Katu (spicy) Rasatmak (taste) Laghu (Light), Ruksha (Dry) and Guru Guna (Heavy in nature) and combination of Ushna(Hot) \& Shita(Cold) Virya drugs exhibiting Tridosh Shamaka ( Pacify all three energies) property. Tikata Rasa is beneficial for Daha (Burning) and Kandu.(9)It act on Pittaj and Kaphaj Vyadhi.(10) It is considered to be ideal in all Twak Vikar (Skin disease) ${ }^{(11)} \cdot$ Kashay Rasa is described as Kapha Pittaghna and Raktaprasadak (Improve blood) which is primarily essential to achieve cure of symptoms in Sheetpitta. Most of the drugs of Navkarshik Kwath Ghan posses with Katu Rasa and Katu Vipaki which act on Sheetpitta.(12) Due to predominance of Ushna Virya in the composition of Navakarshik Kwath Ghan brings about pacification of Vata Dosha and relives symptoms like Vedna ( Pain). Krumi is mentioned as a causative factor of Sheetpitta. So, Krumighna Dravya ( Worms destroying drugs) of this medicine might be effects on Krumi ( Worms).

\section{Conclusion}

This study was conducted to analyse effect of Navakarshik Kwath Ghana in Sheetapitta. The Rate of ESR is elevated in Sheetpitta it has been significantly decrease by Navakarshik Kwath Ghana. Urticarial activity score is improved and Itching score also was reduced in all patients. Internal use of Navakarshik Kwath Ghana is found effective in the severity of itching. No side effect of Navakarshik Kwath Ghana was observed in any patient. 


\section{References}

1. http://emedicine.medscape.com/article/762917overviews, html date 13 June, 2018

2. Sehgal VN, Clinical Dermatology, 4th edition ,New Delhi, 2004, p.91.

3. Shukla and Ravi Dutt Tripathi, Agnivesh, Charak samhita, Chakrapani Commentary, Sutrastana, Chapter 25, shloka 465 , Varanasi:Chowkhamba Sanskrit Pratishthan 2010.

4. Murthy K.R.Srikanta, Madhava Nidanam (Roga Viniscaya) of Madhavkara, Nidan, Chapter 50, Shloka 01, Varanasi, Chaukhambha Orientila 2001, p. 165

5. Shastri Ambikadata, Bhaishajya Ratnavali, , chapter 55, Shloka 3, New Delhi: Chaukhamba Sanskrit Bhavan, 2008, p.916

6. Patel RM. et.al Clinical Study of Urticaria and Angioedema with Particular reference to the
Etiology. Natl J Med Res., volume 4, issue 2, 2014, p.132-137.

7. I Jáuregui et. Al Assessment of Severity and Quality of Lifein Chronic Urticaria J Investig Allergol Clin Immunol ,Vol. 24, issue 2, 2014, p. 80-86

8. Anthony S. , Harisons principle of internal medicine, Vol 2, 2008, P. 2065.

9. Shukla and Ravi Dutt Tripathi, Agnivesh, Charak samhita, Chakrapani Commentary, Sutrastana, Varanasi:Chowkhamba Sanskrit Pratishthan ,2009 p.144.

10. Tripathi Brahmanand ed. Ashtang hridaya, Delhi, Chaukhmba Sanskrit Pratishthan, 2009, p. 154.

11. Shukla and Ravi Dutt Tripathi, Agnivesh, Charak samhita, Chakrapani Commentary, Sutrastana, Varanasi:Chowkhamba Sanskrit Pratishthan ,2009 p.144.

12. Tripathi Brahmanand ed. Ashtang hridaya, Delhi, Chaukhmba Sanskrit Pratishthan, 2009, p. 154. 